\title{
Van Gölü'nün Korunmasına Yönelik Yapılan Faaliyetlerinin Değerlendirilmesi: Adilcevaz, Ahlat ve Tatvan Belediyeleri Örneği*
}

\author{
Evaluation of the Activities Carried Out for the Protection of Lake Van: The Example of the \\ Municipalities of Adilcevaz, Ahlat, Tatvan
}

\section{Vedat YILMAZ}

Doç. Dr., Malatya Turgut Özal Üniversitesi,

Sosyal ve Beşeri Bilimler Fakültesi,

Kaти Yönetimi Bölümü, vedatyilmaz1977@gmail.com

https://orcid.org/0000-0003-4624-9824

\section{Muhammed Cihat GÜNAY}

Yüksek Lisans Öğr., Van Yüzüncü Yll Üniversitesi,

SBE, Кати Yönetimi A.B.D., gunaycihat@hotmail.com

https://orcid.org/0000-0001-9139-6028
Makale Başvuru Tarihi: 01.12.2021

Makale Kabul Tarihi: 24.12.2021

Makale Türü: Araştırma Makalesi

ÖZET

\begin{abstract}
Anahtar
Kelimeler:

Van Gölü,

Belediye,

Adilcevaz,

Ahlat,

Tatvan,
\end{abstract}

Keywords:
Van Lake,
Municipality,
Adilcevaz,
Ahlat,
Tatvan,

\section{Keywords:} ABSTRACT
Water is one of the most important life sources necessary for the life of living beings. Economic, cultural, and
sociological aspects of water have had the potential to primarily affect human life from past to present. In this respect, it is important to ensure the sensitivity required for the protection and use of underground and groundwater. As in Turkey on behalf of the world to find solutions to problems, depending on the subject it carries out important activities in local governments. In this study, an awareness about the protection of surface waters is tried to be revealed. Activities of local governments for the protection of Lake Van in Eastern Anatolia Region of Turkey were investigated. Most of the waters of the lake are located within the borders of the province of Bitlis. In the study, the activities of Bitlis provincial municipality, Adilcevaz, Ahlat and Tatvan district municipalities, located on the shore of the lake were investigated. Qualitative research method was used as a method in the study and face-to-face interviews were conducted with Bitlis provincial mayor, district mayors and deputy mayors during the data collection process. In the study; it is concluded that the activities of Bitlis provincial and district municipalities, where a large part of the Van Lake is located, are generally not sufficient in terms of protecting the lake and utilizing the lake resource.

* Bu çalışma 21-22 Temmuz 2020 tarihinde gerçekleştirilen “Al Farabi 8. Uluslararası Sosyal Bilimler Konferansı”nda sunulan "Bitlis il ve İlçe Belediyelerinin Van Gölü’nün Korunmasına Yönelik Yapılan Faaliyetlerinin Değerlendirilmesi” başlıklı bildirinin genişletilmiş ve güncellenmiş halidir. 


\section{GIRISS}

Türkiye'de Doğu Anadolu Bölgesinde yer alan, kendine özgü kimyasal özellikleri ile öne çıkan, Van ile Bitlis İli sınırları içerisinde bulunan Van Gölü, Türkiye'nin en büyük, Ortadoğu'nun ise ikinci büyük gölüdür. Bu özelliğiyle hem ulusal hem de uluslararası alanda farklı bir statüsü olan gölün önemi yadsınamaz düzeydedir. Van Gölü kendi kimyasal özellikleri ile birlikte tabanında bulundurduğu uranyumla dikkatleri üzerine çekmektedir. Tuzlu ve sodalı suyu ile hem kendi kendini temizleme özelliğiyle hem de sudan elde edilen ürünler ile farkını ortaya koymaktadır.

Van Gölü ve kıyıları, bulunmuş olduğu yerleşim alanlarının turizm, kültür ve tarihine mihmandarlık yapabilecek düzeye getirilmesi bakımından önemli firsatlar sunmaktadır. Bu noktada özellikle kıyı şeridinde yer alan yerel yönetimlere önemli görevler düşmektedir. Yerel yönetimler merkezi iradeninde desteğini alarak Van Gölü’nün korunması, tanıtılması ve geliştirilmesi konularında işlevlerini artırmaları önem arzetmektedir. Bu çalışmanın temel amac1 da belirtilen konularda yerel yönetimlerin faaliyetlerinin gündeme getirilmesidir.

Çalışmada, Van Gölü kıyılarının çoğunlukla sınırına sahip Bitlis İline bağlı Adilcevaz, Ahlat ve Tatvan İlçe belediyelerinin Van Gölü'nün korunması, göldeki çeşitli canlı yaşamının sürdürülebilinmesi ve turizmin geliştirilmesine yönelik faaliyetleri incelenmektedir. Çalışmada yöntem olarak literatür taraması, yüz yüze görüşme ve gözlem kullanılmış olup, Adilcevaz, Ahlat ve Tatvan belediye başkanlıkları ile yüz yüze görüşmeler yapılmıştır. İlgili konularda ilçe belediyelerinin günümüze kadar yapmış oldukları faaliyetleri, devam edilen faaliyetleri ve gelecekte planlanan faaliyetleri hakkında genel olarak bilgiler edinilmiştir. Çalışmaya ilişkin Van Yüzüncü Yıl Üniversitesi Etik Değerlendirme Kurulunda gerekli olan izin alınmıştır.

\section{TARIHHSLL SÜREÇTE BELEDIYYLER}

Yerel yönetimlerin gerekliliği, varlığı ve geleceği genel anlamda bir demokrasi meselesi olduğu gibi yerel demokrasinin ve katılımcılığın sağlanması ve korunması da yerel demokrasinin gerekliliğidir. Bu gereklilik yerel yönetimler denilince ilk olarak akla gelen belediyeler konusu üzerinden ele alınmıştır. Osmanlı Devletinden günümüze kadar ki süreç genel olarak değerlendirilmiştir.

Osmanlı İmparatorluğu döneminde şehir yönetimleri de devlet yönetimi gibi tek elde toplanmıştı. Elbetteki tarihi kendi içinde değerlendirirken konuyu zaman ve zemin birlikteliğinden bağımsız ele almak "tarihi" bir hata olarak karşımıza çıkacaktır. Dolayısıyla dönemin gereği şehir yönetimleri hem idari, hem de adli yetkili ve atamayla başa gelen kadıya bırakılması bu açıdan değerlendirilmedir ki kadının buradaki varlığını beledi hizmetler yerine getirilirken "gözeten" ve "yönlendiren" vasıflarıyla değerlendirmek gerekmektedir. Osmanlı devletinin iki önemli özelliği olan "teşkilatçıllk" ve "vaklf kültürrünün" yerelde de karşllık bulduğu göze çarpmaktadır. Bu bağlamda, beledi yönetimini elinde bulunduran kadının mahalle temsilcileri ve naiplik ile yerelde teşkilatçıllı̆̆; beledi hizmetlerde halkın zaman zaman inisiyatif alması vakıf kültürünü ortaya çıkarmaktadır. Bir açıdan yerelde katılımcılığın varlığına kanıt sunan bu iki özellikten mülhem olmaktadır ki belediye yönetimlerine geçiş zor olmamış, hatta Osmanlı-Türk idari teşkilatının en eski organlarından olan belediye, önemlerini günümüze kadar artırarak devam ettirmişlerdir. Bu noktada dikkat edilmesi gereken bir husus da yerel ile imparatorluk arasındaki paralel geçişkenliktir. Genelde gücün tek elde toplandığı padişahlık sistemi ile yerelde gücün tek elde toplandığ kadılık sistemi; zamanla gücü kaybeden padişah ile yerel yönetimde kadıdan İhtisab Teşkilatı'na geçen yönetim yetkisi bu durumu somutlaştırmaktadır (Parlak, 2020:197-198).

Zaman, kuram ve kurum olarak "şehremaneti" ile "kadı" arasında bir konumda olan İhtisab Teşkilatı denetim yetkisiyle var olmuştur. Nitekim şehremaneti kurumu da ilk kuruluş aşamasında ayrı bir kamu tüzel kişiliği olmayan, fakat denetleyici olan; yerel yönetim olarak değil, merkeze bağlı bir yönetim olarak tasarlanmıştır. Temizlik gibi bazı hizmetleri yerine getirmekle görevli bir idari teşkilat olduğu da söylenebilir (Ortaylı, 1990:70). Şehremaneti kurulmasının öncesinde, İhtisab Nezareti'nin ulaşım ile ilgili, yatırımcı değil, denetleyici bazı yetkileri bulunmaktaydı. İlk kuruluşta Şehremaneti'ne bu yetkilerin verilmemiş, olmasının sebebi, öncelikle bu yeni idarenin ayrı hukuki kişiliğe sahip bir yerel yönetim kurumu olarak düşünülmemesi, kentin temizlik işleri başta olmak üzere bazı yerel hizmetlerin yürütülmesi ile görevli idari bir teşkilat olarak öngörülmüşs olmasıyla ifade edilebilir (Ortaylı, 1990: 70). Bu noktada esas olan ilke, hizmette halka yakınlık anlayışıdır. Buna göre hizmetlerin yerine getirilmesi hususunda "yerinde" ve "yerinden yönetim" anlayışı hâkim kılınmaktadır (Keleş, 1995:6). 
Anayasanın 127. maddesiyle Türkiye'de mahalli düzeydeki müşterek ihtiyaçların karşılanması maksadıyla, merkezi yönetimin haricinde, karar organları seçimle iş başına getirilen mahalli idareler (yerel yönetimler) kurulmuştur (Mecek ve Doğan, 2015:225). Yerel yönetimler merkezi yönetimlere klyasla vatandaşa olan mekansal yakınlık ve icrai bir yapı olması dolayısıyla ilk müracaat yeri ve kamusal ihtiyaçların daha etkili ve hızlı bir şekilde karşılandığı birimlerdir (Tunç, 2016:77; Kaypak vd., 2017:1800). Özellikle belediyeler yerel halka en yakın yerel yönetim birimi olarak öne çıkmaktadır.

Türkiye'de modern belediye idaresinin kuruluş belgesi olan 1854 tarihli Şehremaneti Nizamnamesi'ne göre bu idarenin yapması gerekenler; şehir halkının günlük ihtiyaç maddelerini karşılamada olanak sağlamak, fiyatları tespit etmek, çarşı-pazar düzenini sağlamak ve vergilerin toplanmasının kolaylaştırılmasıdır (Ergin, 1995:1353). 1864 Vilayet Nizamnamesi ve 1868 Dersaadet İdare-i Belediye Nizamnamesi ile birlikte belediyenin görev tanımı daha da genişlemiştir. 1854 tarihli Şehremaneti Nizamnamesine göre ulaşımla birlikte altyapı işleri de belediyenin görev tanımı içine girmiştir (Ortaylı, 2000:158; Akınc1, 2019:99-117).

Cumhuriyet'in ilk yılları da dikkate alındığında belediye hizmetinin kim tarafından ve ne şekilde yerine getirileceği çeşitli ve yakın tarihlerin kanunlarına konu olmuştur. Cumhuriyet öncesi dönemde beledi hizmeti yerine getiren yöneticilerin atama usulüyle görev başına getirilmeleri şehrin yönetiminde çeşitli sorunlar doğurmuş̧tur. Bu duruma merkezin bütçesine bağlı olması da eklenince sorunların ekonomik ve yönetimsel çeşitli kaynakları olmuştur. Erken Cumhuriyet döneminde belediyelerin ekonomik yeterliliğinin sağlanması noktasında çeşitli adımlar atılmıştır. Bu noktada özel sektörden elde edilen gelirlerden belediyelere özgü paylar sağlandığg görülmektedir (Öztürk, 2010:86- 87).

Cumhuriyetin ilk yıllarından itibaren 1970'li yıllara kadar belediyelerin görev tanımı belediye hizmetlerinin sınırlarını oldukça aşmıştır. Özellikle merkezin yönetim anlayışıyla paralellik gösteren yönetim anlayışı yerele de yansımıştır. Belediye sınırları içerisindeki nüfusun ve toplu yapıların sayılarının çoğalması, mahalli müşterek ihtiyaçların nitelik ve niceliğinin artmasına yol açması sebebiyle daha geniş bir yönetim perspektifini zorunlu kılmıştır (Güler, 2021:31). Nitekim 1970'li yıllardan itibaren belediyelerce birtakım yetkiler ve görevler talep edilmiştir (Tekeli, 1990:52).

Tarihsel süreç içerisinde belediyelerin yasal gelişimlerine bakıldığında 1930-2005 yılları arasında, 75 yıl yürürlükte kalan 1580 sayılı belediye kanununa göre hareket edilmiştir. Bu süre zarfında yapılan önemli değişikliklerden biri de büyükşehir belediyesi sisteminin yürürlüğe konulmasıdır (Parlak, 2000:205). Büyükşehir belediye sistemi 1984 yılında 3030 sayılı yasa ile yürürlüğe girmiştir.

2004 ve 2005 yıllarında değiştirilen yerel yönetim yasaları ile yerel yönetimler konusundaki reform çalışmaları hız kazanmıştır. Söz konusu yasal düzenlemelerde önemli bir yeri olan (Tunç vd, 2019:259) 2005 tarihli 5393 sayılı belediye kanununun 3. maddesine göre belediyenin tanımı, "belde sakinlerinin mahalli müşterek nitelikteki ihtiyaçlarını karşılamak üzere kurulan ve karar organı seçmenler tarafindan seçilerek oluşturulan idari ve mali özerkliğe sahip kamu tüzel kişisidir", şeklinde yapılmıştır. Günümüzde belediye sayıs1, türlerine göre şu şekildedir; büyükşehir belediye sayısı 30, il belediye sayısı 51, ilçe belediye sayısı 922 ve belde belediye sayıs 386 olmak üzere toplamda belediye sayıs1 1389'dur (E-İcisleri, 2020).

2012 tarih ve 6360 sayılı Kanun ile Türkiye'nin yönetsel yapısında köklü düzenlemelere gidilmiştir. Merkezi yönetim birimlerinden olan ve her geçen gün etkinliğini kaybeden "bucak" yönetimi önce büyükşehirlerde, sonrasında (2014 yılında 5442 sayılı yasada yapılan düzenlemeyle) ise bütün ülkede tamamen kaldırılmıştır. Kanun ile herhangi bir il belediyesinin büyükşehir belediyesi olabilmesi için, il mülki sınırları içerisinde toplam 750 bin nüfus koşulu getirilmiştir. Bu koşul büyükşehir olmadaki tek ölçüttür. Kanun ile büyükşehir belediyesi sınırı, il mülki sınırı olacak şekilde tekrar düzenlenmiştir. Büyükşehir belediyesi içinde öncesinde mevcut olan "ilk kademe belediyeleri" ve "kasaba belediyeleri" tüzel kişilikleri kaldırılarak bağımsız bir yerel yönetim birimi olmayan "mahalleye" dönüştürülmüştür. Büyükş̧ehir belediyesi olan illerde bulunan il özel idareleri ve köylerin tüzel kişilikleri kaldırılmış ve köyler mahalleye dönüştürülmüştür (Mecek ve Atmaca, 2020:2072; Kaypak ve Yılmaz, 2016:32). Büyükşehir belediyeleri ile ilçe belediyeleri arasındaki görev ve yetki paylaşımları yeniden yapılmıştır. $\mathrm{Bu}$ durumun ortaya çıkmasında teknolojik değişimlerin, üretim araçlarındaki dönüşümlerin, kamu hizmetlerine yönelik taleplerdeki farklılaşmanın, katılım mekanizmalarının genişlemesi ve çok daha etkin olarak kullanılması ile yeni yönetim teknikleri ve ilkelerinin kullanılması etkili olmuştur.

2000’li yıllar ile teknolojik gelişmeler daha da büyük verilerin hızlı, kolay ve az maliyet ile elde edilmesine, depolanmasına, işlenmesine, analiz edilmesine ve ürün olarak kullanılmasına olanak sağlamıştır. Yerel ve bölgesel nitelikteki veriler ulusal ve hatta bazen küresel düzeyde birbirine entegre edilmiştir. Kullanılan teknolojiler yenilenerek daha hızlı, etkin, güvenli ve konforlu bilgi/hizmet akışı sağlanmıştır. İnsanlar arasındaki 
ilişki ve etkileşim ağına makineler, akıllı cihazlar, sistemler, ağlar, uygulamalar, eşyalar ve hatta nesneler de dâhil edilmiştir. Özel sektörde ve toplumsal yapıda gerçekleşen bu dönüşüm, kamu yönetimi anlayışında da köklü değişikliklere neden olmuştur (Yılmaz ve Mecek, 2021:103-104). Kamu yönetimi alanında yaşanan söz konusu dijital dönüşüm ile vatandaşların istek ve taleplerinin yerelde hızlı ve güvenilir bir şekilde karşılanması sağlanmıştır (Yılmaz, 2019:513). Bu süreçte toplumsal hayatta önemli değişimler meydana gelmiştir. Bu değişimle birlikte vatandaşların yaşadıkları yerlerde kamusal hizmetlere ilişkin talepleri de giderek değişmiştir (Karaca ve Öztürk, 2019:529).

Kisaca bahsedilen tarihsel süreç göstermektedir ki Türkiye'de belediyeciliğin ve yerel hizmet sunumu anlayışının köklü bir geçmişi ve birikimi bulunmaktadır. Bu geçmiş ve birikim, gelecek vizyonuyla harmanlandığında yerelde gelişimin ve değişimin öncüsü olarak belediyeler önemli bir rol üstleneceklerdir. Konumuz bağlamında değerlendirildiğinde ise belediyelerin Van Gölü'nün korunması ve geliştirilmesi yönünde ortaya koyacakları çalışmalar Van Gölü’nü bölgesine ve ülkesine değer katan bir pozisyona taşıyabilecektir.

\section{VAN GÖLÜ HAKKINDA GENEL BİR DEĞERLENDİRME}

Van Gölü, coğrafi açıdan, "lav seti gölü" olarak yüzyıllar öncesinde yer hareketlerinin etkisi ile meydana gelmiş olup, Üç bin altı yüz yirmi altı kilometrekarelik bir alana sahiptir. Deniz seviyesinden bin altı yüz kırk altı metre yükseklikte bulunan gölün en derin noktasıysa dört yüz elli bir metre olarak bilinmektedir. Gölün kuzeyinde Türkiye'nin 3. büyük dağı olan volkanik Süphan Dağı bulunmaktadır. Gölün oluşmasındaki rol ise lavları ile suyun birikmesini sağlayan, gölün batısında bulunan Nemrut Dă̆g'dır. Van Gölü'ne çeşitli kaynaklarda zaman içerisinde "Ahlat Gölü̈", "Tatvan Denizi", "Erciş Gölü”, "Van Deryası" isimlerinin söylendiği de bilinmektedir ayrıca Van Gölü havzasında yaşam olduğuna ilişkin işaretlerin M.Ö. 15.000 tarihlerine kadar uzandığı da belirtilmektedir (Demirtaş ve Subaş1, 2015:11-12).

Van Gölü tüm varlı̆̆g ile yüzyıllardır tarihe tanıklığını sürdüren önemli bir değerdir. Farklı toplumları havzasında barındıran Van Gölü, tuzlu ve sodalı olduğundan içerisine her canlıyı kabul etmeyen, kendisine bırakılan atıkları kendiliğinden temizleyen kendine özgü yapısı ile geçmiş zamandan itibarı; geleceğe yönelik iyi bir intibayı sağlamaktadır. Fakat bu konuda havzada yer alan yerel yönetimlerin, merkezi yönetimin taşradaki yönetim organlarının ve sivil toplumla beraber vatandaşların da Van Gölü konusunda bilinçlendirildiği yeni ve dinamik bir sürecin işletilmesi gerekmektedir.

Ortadoğu'nun 2. büyük su kütlesi olan Van Gölü, Van ve Bitlis il sınırları içerisinde yer almaktadır. Bitlis'in Adilcevaz, Ahlat ve Tatvan ilçeleri, Van ilinin ise Çaldıran, Edremit, Erciş, Gevaş, Gürpınar, Muradiye, Özalp, Saray, Tuşba, İpekyolu Van Gölü kıyılarında bulunan ilçelerdir. Toplamda 13 yerel yönetimin ev sahipliğinde bulunan kıyıların geçmişten günümüze kadar beklenilen düzeyde geliştirilememiş olması çalışmanın temel konusu olmasının gölün geleceğine ilişkin bazı endişeleri ve umutları bir arada bulundurmanın verdiği düşünceyle çalışma ele alınmıştır.

Van Gölü havzası, Van büyükşsehir belediyesi, Bitlis belediyesi, Bitlis il özel idaresi, belediye başkanlıkları, ilgili bakanlıkların taşra teşkilatları, çeşitli sivil toplum kuruluşları tarafindan yönetilmektedir. Van ili 2013 yılından itibaren yönetim sürecindeki paydaşlığına büyükşehir olarak devam etmektedir. Kıyı çoğunluğu ise Bitlis il sınırları içerisinde yer almaktadır. Bitlis ili kıyı yönetimi paydaşlığını Adilcevaz, Ahlat ve Tatvan ilçelerinin belediye yönetimlerine bırakmıştır. Van ilinde ise büyükşehir olmanın sorumluluğu gereği kıyı yönetimine Van Büyükşehir Belediyesi de doğrudan dâhil olmaktadır ve ilçelerle birlikte çalışmalar yapabilme yetisine sahiptir.

Orta Çağ dönemlerinden itibaren Van Gölü'nde denizcilik faaliyetlerinin olduğu bilinmektedir. Özellikle 13. yüzyıldan beri Van, Gevaş ve Tatvan limanı -adeta- hinterlant görevini görmüştür. Nitekim günümüzde de Tatvan ve Van aynı işlevi yerine getirmektedir. Kanuni döneminde Zal Paşa Gölün güvenliğini ve işleyişini sağlamak maksadıyla Tatvan limanı civarında bir kale inşa ettirmiştir. Yine Kanuni dönemi vezirlerinden olan Lütfi Paşa tarafından gemiler inşa ettirilmiştir. Dönemin devlet büyüklerinin de şahıslarına ait gemileri olduğu rivayet edilmektedir. Gemi sayısının Evliya Çelebi tarafından elli olduğu ifade edilmiştir. Gemilerin göldeki varlığı ise ticaret olduğu belirtilmektedir. Ticari faaliyetlerin yoğunluğu sonucunda gemilerden vergi alındığ 1 görülmüştür. 19. Yüzyılın başlarındaysa 70 kadar geminin olduğu her birinin yaklaşık 25 kişilik olduğu, yolcu ve yük taşımacılığı amacıyla kullanıldığı ifade edilmiştir. Kanuni döneminde yapılan seferlerde de göl üzerinden yapılan sevkiyatlar ile orduya destek sağlanmıştır (Demirtaş ve Subaşı, 2015:16-33).

Cumhuriyet dönemine kadar inişli-çıkışli; küçüklü-büyüklü yapılan gemicilik ve denizcilik faaliyetleri Van Gölü Feribot İşletmesi ile daha profesyonel ve daha modern bir zemin bulmuştur. Bu durumun olumsuz yanları 
da yok değildir. Nitekim özel teşebbüsler geri çekilmek zorunda kalmıştır. Gelir kaybı ile birlikte gölün kullanımı Tatvan ve Van arasında genellikle yük trenlerinin taşınması esasına dayandırılmıştır günümüzde de bu şekilde bir faaliyet ağ devam etmektedir.

\section{VAN GÖLÜ’NÜN KORUNMASINA YÖNELİK ALAN ARAŞTIRMASI}

Çalışmanın bu kısmında Van Gölü kıyılarının çoğu sınırlarında bulunan Bitlis iline bağlı Adilcevaz, Ahlat ve Tatvan ilçe belediyelerinin Van Gölü’nün korunması, göldeki canlı yaşamının sürdürülmesi ve turizmin geliştirilmesine ilişkin faaliyetlerini değerlendirmek üzere ilgili belediyelerin başkan ve başkan yardımcılarıyla yapılan yüz yüze görüşmeler değerlendirilmiştir.

\subsection{Araştırmanın Metodolojisi}

Çalışmada, Van Gölü kıyılarının çoğu sınırlarında yer alan Bitlis iline bağlı Adilcevaz, Ahlat ve Tatvan ilçe belediyelerinin Van Gölü’nün korunması, göldeki canlı yaşamının sürdürülmesi ve turizmin geliştirilmesine ilişkin faaliyetleri bulunmaktadır. Bu çalışmanın amacı da bahsedilen faaliyetlerin gündeme getirilmesidir. $\mathrm{Bu}$ bağlamda veri toplama yöntemi olarak gözlem ve yüz yüze görüşme metodları kullanılmış olup. 16/06/202017/06/2020 tarihleri arasında Adilcevaz, Ahlat ve Tatvan belediye başkanlıklarıyla yüz yüze görüşmeler yapılmıştır. İlgili konularda ilçe belediyelerinin günümüze kadar yapılmış çalışmaları, devam eden çalışmaları ve gelecekte planlanan çalışmaları hakkında genel olarak bilgiler edinilmiştir. Çalışmaya ilişkin Van Yüzüncü Y1l Üniversitesi Etik Değerlendirme Kurulundan gerekli olan izin alınmıştır.

\subsection{Van Gölü'ne Yönelik Adilcevaz Belediyesinin Faaliyetleri ve Değerlendirilmesi}

Adilcevaz, 1315 tarihli Van Salnamesi'nde cevizler vadisi olarak ifade edilmektedir. Tarihi ise Kalkoltik Döneme kadar uzanmaktadır. 1071 Malazgirt Zaferi, Adilcevaz-Ahlat-Malazgirt üçgeninde kalan bir bölgede Türk-İslam dünyasına kazandırılmıştır. 29 Mayıs 1855 tarihli Amasya Antlaşması ile Adilcevaz kesin olarak Osmanlı himayesine girmiştir. 23 Mayıs 1915 tarihinde Rus işgaline uğrayan Adilcevaz halkı aynı zamanda Ermeniler tarafından da çeşitli katliamlara maruz kalmıştır. Hem Rus hem de Ermeni mezaliminden kurtulmak isteyen halk göç etmek zorunda kalmıştır. 03 Mart 1918 tarihindeyse Rus işgalinden resmen kurtulmuştur. 2019 y1lı verilerine göre nüfusu 30.499, 2020 verilerine göre ise nüfusu 30.530 kişidir (Adilcevaz, 2020; www.nufusu.com, 2021).

Adilcevaz, Van Gölü'nün en uzun sahil şeridine sahip ilçe olarak tanınmaktadır. Nüfus olarak Tatvan ve Ahlat'tan sonra gelen ilçe, Süphan Dağı'na sırtını vermiş olup önüne de Van Gölü'nü ve kıyılarını almıştır. Adilcevaz'da Ahlat gibi tarihi yapıları ve doğal güzelliği ile ön plana çıkmaktadır. Kıyıları Tatvan ve Ahlat'a göre turizm için daha elverişlidir.

Van Gölü’nün korunması, geliştirilmesi ve turizme kazandırılması için Adilcevaz belediyesinin yapmış olduğu faaliyetler Adilcevaz Belediye Başkan Yardımcısıyla 16.06.2020 tarihinde yapılan görüşme sonrasında ulaşılan bilgiler şunlardır;

1. 2015 yılına kadar atıklar arıtılmadan Van Gölü'ne deşarj edilirken, 2015 yılında yapılan arıtma tesisi ile bu sorunun giderildiği ve tam kapasiteyle arıtma tesisinin faaliyet gösterdiğ

2. Bitlis ili sınırlarında gölün en uzun kıyı şeridine Adilcevaz ilçesinin sahip olduğu,

3. Gölün etrafının belirli periyotlarla temizlendiği, ayrıca Adilcevaz Meslek Yüksekokulu ve ilçede bulunan Milli Eğitim Bakanlığına bağlı okullar tarafından da zaman zaman ilçenin kıyı şeridinin temizliğinin yapılmasına katkı sağladıkları,

4. İlçenin kıyı şeridine belediye tarafından kadın ve erkeklere yönelik ayrı ayrı plajların yapıldığı,

5. Van Gölü Belediyeler Birliği tarafindan yapılan koordinasyonlara katılımların sağlandığı,

6. Van Gölü aktivistleriyle görüşmelerin yapıldığı,

7. Şehir merkezine yakın bir mevkide Bitlis İl Özel İdaresi tarafından Sukay Projesinin gerçekleştirilerek su sporlarına ve eğlencelerine katkı sağlandığı, bu projeyle yerli ve yabancı turistlerin ilçeye kazandırıldığ 1 fakat yaz süresinin kısa olmasından kaynaklı ilçeye olan katkısının istenilen seviyede olmadığı, 
8. İlçede bulunan plajların yanına yeni plajların yapılacağı,

9. Göle ve ilçeye hâkim bulunan Gabanlar mevkiine seyir terası kurulacağı,

10. Gölün etrafina Bungalov evlerin yapılacağı bilgilerine ulaşılmıştır.

Adilcevaz ilçe belediyesi gölün korunması, geliştirilmesi ve turizme kazandırılmasına ilişkin faaliyetler gerçekleştirdiği ve geleceğe yönelik planlamalarının olduğu, fakat yapılan ve yapılması planlanan faaliyetlerin bekleneni karşılayacak düzeyde yeterli olmadığı açıktır. Özellikle deniz turizmine ilişkin herhangi bir faaliyetlerinin olmayışı ve Tatvan ile Van ili arasında ulaşımı sağlayan gemilerin Adilcevaz'a uğramadan geçmesi, Bitlis İl Özel İdaresi tarafından büyük beklentilerle yapılan sukay projesinin isteneni karşılayamaması ve kısa aralıklarla arızaların yaşanması ilçede beklenilen yerli ve yabancı turistlerin sayısını azaltmıştır. İlçede derelerin düzensiz bir şekilde göle akmasının kirliliğe sebep olması, gölün kıyı şeridinde özellikle yaz mevsiminde yaşanan kalabalıktan dolayı ortaya çıkan kıyı şeridindeki çevre kirliliğinin yeterli seviyede önlenememesi ilçede görülen öne çıkan sorunlar olarak ifade edilebilir.

\subsection{Van Gölü’ne Yönelik Ahlat Belediyesinin Faaliyetleri ve Değerlendirilmesi}

Ahlat, Süphan Dağıyla Nemrut dağı arasında yer alan plato üzerinde bulunmaktadır. Coğrafi özellikleriyle dikkat çeken Ahlat, Selçuklu Devleti'ne de başkentlik yapmıştır. Osmanlı Devleti'nin 1639 yılında İran ile yaptığ Kasr-1 Şirin antlaşmasıyla beraber Ahlat kesin olarak Osmanlı himayesine girmiştir. 1914 y1lında uğradığ1 Rus işgalinden 21 Şubat 1916 tarihinde kurtulmuştur. 1929 yılında Van iline bağlanan ilçe, 1936 yılından itibaren Bitlis iline bağlanmıştır. İlçenin 2019 yılı nüfusu 40.699 kişi olup, 2020 yılı nüfusuysa 41.633 kişidir (Ahlat, 2020; www.nufusu.com, 2021).

Ahlat, Bitlis ilinin kıyı şeridinde bulunan üç ilçesinden biri olmasına ilaveten Selçuklu Devleti’nin başkenti olma özelliğiyle tarihte yerini alan önemli bir şehirdir. Tatvan'dan sonra büyüklük bakımından ikinci sırada bulunan Ahlat, bir kültür ve turizm kenti olma yolunda emin adımlarla ilerlemektedir. Özellikle son yıllarda 1071 Malazgirt Meydan Muharebesi'nin anma etkinliklerinin kutlandığı ilçede Cumhurbaşkanlığı Külliyesi de inşa edilmektedir. Bununla birlikte tarihten aldığı sıfatı geleceğe taşıma noktasında önemli bir mevziiyi yakalama noktasındadir.

Ahlat ve Adilcevaz'1 göl konusunda Tatvan'dan farklı kılan en önemli husus kıyı şeridinin uzunluğudur. Özellikle son yıllarda doğu ve güneydoğu gölgesinin yaz sıcağından bunalan yerli turistler Ahlat ve Adilcevaz'a yoğun şekilde ilgi göstermektedir. Selçuklu başkenti olması nedeniyle kültür turizmine ve kıyı şeridinde olduğu içinde yaz aylarında tatil için verimli bir ortamı sunmaktadır. Örneğin, yüzmeye ve deniz ulaşımına elverişli olan gölün Ahlat tarafinda doğal oluşumlarla meydana gelmiş üç plajı bulunmaktadır. Göl, rekreasyonel etkinlikler kapsamında su sporları ve eğlence aktiviteleri yapılmasına elverişlidir (Çelik ve Meriç, 2017:311). Van Gölü kıyılarının genel bir sorunu olarak bakımsız olması elverişli ortamı her zaman ters yönde etkilemektedir.

Van Gölü'nün korunması, geliştirilmesi ve turizme kazandırılması için Ahlat Belediyesi'nin yapmış olduğu faaliyetler Ahlat Belediye Başkanı ile 16.06.2020 tarihinde yapılan görüşme sonrasında ulaşılan bilgiler şunlardır;

1. 2012 yılına kadar atıklar arıtılmadan Van Gölü'ne deşarj edilirken 2012 yılında yapılan arıtma tesisi ile bu sorunun giderildiği ve tam kapasiteyle arıtma tesisinin faaliyetinin devam ettiği,

2. Kıyı şeridine yapılacak yatırımların afet kodu nedeniyle yapılamadığını, bunun bir sorun olduğu,

3. Derelerin düzensiz bir şekilde göle akmasının kirliliğe ve suların zayi olmasına neden olduğu, bu konuda, düzensiz suların göle bırakılmadan bir araya getirilmesini ve bu sayede hem tarımda hem de enerji üretiminde kullanılarak fayda elde edilmesi gerektiğini,

4. Göle bırakılan sularda bulunan kimyasal maddelerin gölün yapısını bozmasından duyduğu endişeyi,

5. Tam göl kenarında kurulan Cumhurbaşkanlığı Külliyesinin ulusal ve uluslararası toplantılar ile göl turizmine katkıda bulunacağını,

6. Önümüzdeki yaz sezonunda yeni plajların yapılacağını,

7. Gölün korunup geliştirilerek, Ahlat, Adilcevaz ve Tatvan ilçeleri olarak gölün kuzeyinde bir kültür havzası oluşturmanın bölgeye önemli katkılar sağlayacağı, 
8. Çeşitli su sporları etkinlikleri ile hem tanınırlığın artırılması gerektiğini hem de turizmin geliştirilmesi konusunda önemli katkılar sağlanacağını,

9. İlçenin kıyı şeridine belediye tarafından erkek ve kadınlara yönelik ayrı ayıı plajların yapılmış olduğunu belirtmiştir.

Ahlat ilçe belediyesi gölün korunması ve turizme kazandırılmasına ilişkin faaliyetler gerçekleştirdiği ve geleceğe yönelik planlamalarının olduğu, fakat yapılan ve yapılması planlanan faaliyetlerin yeterli seviyede olmadığı söylenebilir. Özellikle deniz turizmine yönelik herhangi bir faaliyetlerinin olmayışı ve Tatvan ile Van ili arasında ulaşımı sağlayan gemilerin Ahlat'a uğramadan geçmiş olması olumsuz bir yön olarak karşımıza çıkmaktadır. İlçede derelerin düzensiz bir şekilde göle akmasının kirliliğe sebep olması, gölün kıyı şeridinde de özellikle yaz mevsiminde yaşanan kalabalık nedeniyle meydana gelen kıyı şeridindeki çevre kirliliğinin istenilen seviyede giderilememesi ilçede görülen, öne çıkan sorunlar olarak sayılabilir. Van Gölü kıyısında yeni yapılan Cumhurbaşkanlığı Külliyesiyle hem bölgede hem Bitlis ilinde hem de Ahlat özelinde ciddi bir tanıtım firsatının yakalandığı açıktır.

\subsection{Van Gölü'ne Yönelik Tatvan Belediyesinin Faaliyetleri ve Değerlendirilmesi}

Tatvan, Selçuklu ve Osmanlı Devleti'nin yerleşim yerlerinden birisidir. Özellikle Osmanlı döneminde İran'a yapılan seferlerde önemli bir geçit olma görevi görmüştür. Nitekim Kanuni Sultan Süleyman döneminde gölü korumak ve işleyişini sağlamak amacıyla Taht-1 Van kalesinin kurulduğu bilinmektedir. 1936 y1lında ilçeye dönüştürülen Tatvan, Van ve İran'a ulaşımı sağlayan liman şehri olarak karşımıza çıkmaktadır. Bu durum ilçenin gelişmesinin de önünü açan önemli bir unsurdur (Tatvan, 2020). Tatvan'ın 2019 yılında nüfusu 93.189, kişi iken 2020 yılı nüfusuysa 94.697 kişidir (www.nufusu.com, 2021). Bu durum Tatvan'ın nüfusunun bir önceki yıla göre artış gösterdiği ve gelişmekte olan bir ilçe olduğuna işaret etmektedir.

Tatvan, Van iliyle birlikte Van Gölü'nü en aktif bir şekilde kullanan Bitlis ilinin ilçesidir. Bitlis'in kıyı şeridinde bulunan üç ilçesinden biri olan Tatvan, diğer iki ilçeden (Ahlat ve Adilcevaz) daha büyüktür. Bu büyüklükten kaynaklı olarak belediye kıyasında da aynı durum söz konusudur. Tatvan'ı etkin kılan faktörlerden en önemlisi Muş, Van ve Bitlis illerinin bağlantı noktasını oluşturmasıdır. Üstteki başlıkta da değerlendirildiği gibi Tatvan ve Van arasında göl üzerinden yapılan mal ve insan taşımacılığı yüzyıllardır varlığını korumuştur. Günümüzde de aynı durum devam etmektedir. Fakat çalışmanın ana sorunsalı olan gölün korunmasına ve geliştirilmesine ilişkin Tatvan Belediyesi'nin bu konudaki çalışmaları nelerdir ve yapılması gereken çalışmaların neler olduğu sorularına cevap olacak şekilde aşağıdaki görüşme notlarının sağlayacağı katkı çerçevesinde değerlendirilmiştir. Nüfus olarak diğer iki ilçeden daha fazla olması ilçeyi daha güçlï bir konuma taşımaktadır.

16/06/2020 tarihinde Tatvan Belediyesinde sırasıyla İmar ve Şehircilik Müdürü, Feribot İşletmesi Eski Müdürü Şükrü Çelikyürek ve Belediye Başkan Yardımcısı ile görüşmeler yapılmıştır. İlk görüşme yapılan İmar ve Şehircilik Müdürü Tatvan ilçesinde yapılan çalışmaları şöyle ifade etmiştir;

- Tatvan sahil bandından ilk olarak sayı tahkimatı yapılmıştır, ardından dolguyla yollar ve parklar oluşturulduğunu,

- 100 dönümden fazla bir alan yeşil alan ve park olarak oluşturulduğunu,

- Özellikle son 15 yıldır gölün korunması ve geliştirilmesine yönelik çalışmaların yapıldığını,

- Yüzme alanı olarak kent merkezinden yaklaşık sekiz kilometre uzaklıkta bir kıyı şeridinin olduğunu,

- Sahil bandında bisiklet yolu yapıldığını,

- Van Gölü Aktivistlerinden haberdar olunduğunu belirtmiştir.

Yapılan bu görüşmeye Feribot İşletmesi Eski Müdürü Şükrü Çelikyürek ise şu ifadelerle katkı sağlamıştır;

- 2005-2006 yıllarında eski feribot alanı olan 60-70 dönümlük alanın belediye tarafından park ve yeşil alan olarak Tatvan ilçesine kazandırıldığını,

- Tatvan ilçesinde gölle ilgili çalışmaların özellikle 2005 yılından sonra başladığını ifade etmiştir.

Van Gölü'nün korunması geliştirilmesi ve turizme kazandırılması için Tatvan Belediyesi'nin yapmış olduğu faaliyetleri Tatvan Belediye Başkan Yardımcısı aşağıdaki şekilde ifade etmiştir; 
- 2007 y1lına kadar atıklar arıtılmadan Van Gölü’ne deşarj edilirken 2007 yılında arıtma tesisi yapılarak bu sorunun giderildiği ve tam kapasiteyle arıtma tesisinin faaliyetini sürdürdüğü,

- Temizlik projesi ile kıyı şeridinin temiz tutulmasının planlandığını,

- Dalgıç ekibi oluşturularak su altında da temizlik faaliyetlerinin gerçekleştirildiğini,

- Temizlik projesi kapsamında iş makinesinin alındığını, bunun için 50-60 milyonluk bir yatırımın gerçekleştirildiğini,

- Marina Projesinin önümüzdeki yaz sezonu için sonuçlandırılacağını,

- Bakanlık bünyesinde sağlanan koordinasyona mevcut belediye başkanının katılım sağladığını,

- Van Gölü’nü koruma ve geliştirme noktasında yerel halka yönelik bilinçlendirme çalışmalarının sürdürüldüğünü,

- Son olarak Van Gölü Aktivistlerinden haberdar olunduğunu belirtmiştir.

Tatvan ilçe belediyesi gölün korunması ve turizme kazandırılmasına yönelik faaliyetler gerçekleştirdiği ve geleceğe yönelik planlamalarının olduğu, ancak yapılan ve yapılması planlanan faaliyetlerin yeterli düzeyde olmadığı aşikardır. Özellikle deniz turizmine yönelik herhangi bir faaliyetlerinin olmaması Tatvan ve Van ili arasında ulaşımı sağlayan gemilerin Tatvan'ın ve Van Gölü'nün tanıtımı noktasında iyi bir firsat olduğu açıktır. Tatvan'ın tarihten gelen avantajlı konumunun günümüze kadar artırılarak sürdürülememiş olması önemli bir kayıp olduğu söylenebilir. İlçede derelerin düzensiz bir şekilde göle akmasının kirliliğe sebep olması, gölün kıyı şeridinde özellikle yaz mevsiminde yaşanan kalabalıktan dolayı ortaya çıkan kıyı şeridindeki çevre kirliliğinin yeterli seviyede önlenememesi ilçede görülen başlıca sorunlar olarak sıralanabilir. Kıyı imkânlarının görece kısıtlı olduğu Tatvan, yapılacak çeşitli yatırımlar ile ulaşımın göl üzerinden hem mal hem de yolcu taşımacılığı için elverişli bir yapıya sahiptir. Özellikle Marina projesi bu konuda dikkat çekicidir.

\section{SONUÇ}

Van Gölü, ülke ve bölge coğrafyası bakımından değeri tartışılmaz bir öneme sahiptir. Havzasında bulundurduğu halka çeşitli özellikleri ile yüzyıllardır hizmet sunmakta olan gölün, yerel yönetimler tarafından hangi ölçïde korunup geliştirildiği bu çalışmanın temelini oluşturmaktadır. Yerel yönetimlerin, halkın yönetime doğrudan katılımının sağlandığı en önemli birimler olmasından dolayı, doğal varlıkların yerel halkın ihtiyaç ve talepleri doğrultusunda korunması, geliştirmesi ve geleceğe taşınması noktasında sorumluluk üstlenmesi en haklı beklenti olarak karşımıza çıkmaktadır.

Kıyı şeridinde yer alan belediye yönetimlerinin Van Gölü havzasından tek başına sorumlu olmadığı bilinmektedir. Ancak toplamda on üç belediye olan Van Gölü havzasında yerel yönetimler sayısal olarak üstünlüğe sahiptir. Bu doğrultuda belediye yönetimlerinin göl politikalarını, gölle ilgili çalışmalarının bölgeye ve bölge halkına hizmet sunacak düzeyde olması önem teşkil etmektedir. Bir doğal kaynak ve doğal zenginlik olan gölün en verimli şekilde halk, doğa ve turizm ile bütünleştirilmesi öncelikli beklentidir. Bitlis ili özelinde yapılan bu çalışma bağlamında görülmüştür ki hala gölün önemi yeterli düzeyde anlaşılamamıştır. Bu durum sadece çalışmanın sonucu değil aynı zamanda bölge insanının da göl ile şikâyetlerinin bir ispatı niteliğindedir.

Tatvan Belediyesi'nin Van Gölü ile ilgili çalışmaları değerlendirildiğinde; Tatvan Belediyesi, Bitlis ilinin diğer ilçeleri ile kıyaslandığında birçok açıdan daha büyüktür. Bu bakımdan Tatvan belediyesinden yerel halkın beklentiside daha büyüktür. Tatvan belediyesi gölün korunmasına yönelik birtakım faaliyetlerinin bulunduğu ancak yapılan faaliyetlerin yeterli düzeyde olmadığ 1 açıktır. Bu durumun nedeni olarak belediye başkan yardımcısı 'yönetimlerin, enerjilerini alt yapı-üst yapı' konularına harcadıklarına dikkat çekmiştir. Elbette ki sudaki canlılardan oy alamayacağını bilen her siyasetçi yatırımını oy alabileceği yerlere kaydıracaktır. Fakat su, bir değerdir ve varlığınında kıymeti bilinmediği için Van Gölü, gün geçtikçe kirleniyor, verimsizleşiyor, değersizleşiyor. Günümüzde hangi belediyenin arıtmaları çalıştırıp çalıştırmadığı ya da hangi kapasite ile çalıştırdığı bile ayrı bir tartışma konusu olarak karşımıza çıkmaktadır.

Ahlat Belediyesi'nin Van Gölü ile ilgili çalışmaları değerlendirildiğinde; Ahlat Belediyesi, Bitlis ilinin diğer ilçelerine göre daha gelişme gösteren bir belediyesidir. Göl ile ilgili çalışmaları ise daha umut vericidir. Gölün korunması ve geliştirilmesi konusunda daha bilinçli bir profili olan mevcut yönetim, gölü koruma ve geliştirme konusunda dinamik bir tavır içinde olduğu, gölün korunması ve geliştirilmesi hususunda diğer paydaşlar ile beraber yol alınması gerektiği düşüncelerinin olması olumlu bir yaklaşımdır. Ahlat belediyesinde gölün 
korunmasına yönelik, arıtma tesisinin yapılması gibi bir takım faaliyetleri bulunmakla birlikte yapılan faaliyetlerin yetersiz ve basit düzeyde kaldığını söylemek yerinde olacaktır.

Adilcevaz Belediyesi’nin Van Gölü ile ilgili çalışmaları değerlendirildiğinde; Adilcevaz Belediyesi, Bitlis ilinin en uzun sahil bandına sahip olan ilçesi olmasına rağmen bu durumdan en az verimi almaktadır. Ahlat ile birlikte yaz aylarında yerli turistlerin ilgi odağında bulunan Adilcevaz, diğer ilçelere kıyasla uzun plajlarıyla ortaya fark koymaktadır. Fakat istenilen seviyede gölün korunduğu ya da gölün nimetlerinden faydalanıldığı söylenemez.

Sonuç olarak görüşme yapılan üç (Adilcevaz, Ahlat ve Tatvan) belediyenin gölün korunması ve geliştirilmesine yönelik yapmış olduğu faaliyetlerin yetersiz olduğu, özellikle derelerin düzensiz bir şekilde göle akmasının önlenmesi, arıtma tesislerinin düzenli bir şekilde kullanılması, gölün korunmasına ve geliştirilmesine yönelik yapılan çalışmaların artırılması, tüm havzada kıyıların turistik seviyelerde geliştirilmesi, turizm kültürünün canlandırılarak istihdam alanı oluşturulması, bölgenin refahına ve güvenliğine dönük alt yapı-üst yapı çalışmalarıyla gölün bir cazibe merkezi haline getirilmesi, gölün ekosisteminin korunması ve geliştirilmesi, gölün uluslararası programlara ev sahipliği yapmasının önünün açılması başlıca beklenti ve öneriler olarak siralanabilir.

\section{KAYNAKÇA}

AKINCI, Berat (2019), "Presidential Government System Model in Local Governments: Case of Gaziantep Metropolitan Municipality", Innovative Approaches in Social, Human and Administrative Sciences (Ed. H. Hale Künüçen, Xatire Quliyeva, Yılmaz Seçgin), Ekin Publishing House, Bursa, ss.99-116.

ÇELIK, Sedat ve MERİÇ, Sağbetullah (2017), “Ahlat'in Rekreasyonel Turizm Potansiyelinin GZTF Analizi ile Değerlendirilmesi”, Siirt Üniversitesi Sosyal Bilimler Enstitüsü Dergisi, S.9, ss.295-311.

DEMİRTAŞ, Mehmet ve Subaşı, Oktay (2015), Osmanlıdan Cumhuriyete Van Gölü Denizcilik Tarihi, Mega Basım Yayın, İstanbul.

ERGINN, Osman Nuri (1995), Mecelle-i Umur-ı Belediye, İstanbul Büyükşehir Belediyesi Yayını, İstanbul, Cilt.1-3.

GÜLER, Fatih (2021), "Kentleşmenin Bireylerin Yönetim Hakkını Zedelemesi Açısından Kat Mülkiyeti Kanununun Yönetim Planına İlişkin Bazı Hükümlerine Eleştirel Yaklaşım ve Öneriler", Paradoks Ekonomi Sosyoloji ve Politika Dergisi, S.17(1), ss.17-34.

KARACA, Yusuf ve ÖZTÜRK, Namık Kemal (2019), "Yeni Nesil Belediyecilik: Dijital Belediye Uygulamalart", Uluslararası Yönetim Akademisi Dergisi, S.2(3), ss.528-537.

KAYPAK, Şafak ve YILMAZ, Vedat (2016), "Hatay Büyükşehir Yapılanma Sonrasında Çevre Sorunlarına Yaklaşım ve Çevre Düzenlemeleri”, Bitlis Eren Üniversitesi Sosyal Bilimler Enstitüsü Dergisi, S.5, ss.25-50.

KAYPAK, Şafak, YILMAZ, Vedat ve BİMAY, Muzaffer (2017), “Dijital Çağda Yerel Yönetimler”, Süleyman Demirel Üniversitesi İktisadi ve İdari Bilimler Dergisi, S.22(Kayfor Özel Say1s1), ss.1798-1813.

KELEŞ, Ruşen (1995), “Hizmette Halka Yakınlık (Subsidiarite) İlkesi ve Yerel Yönetimler”, Çağdaş Yerel Yönetimler Dergisi, S.4(1), ss.3-14.

MECEK, Mehmet ve ATMACA, Yıldız (2020), "Yerel Yönetimlerin İdari Yapısına İlişkin Mevzuat Analizi”, Elektronik Sosyal Bilimler Dergisi, S.19(76), ss.2068-2087.

MECEK, Mehmet ve DOĞAN, Hüsna (2015), "İstihdam Açısından Yerel Yönetimlerin Organizasyon Yapısı ve Personel Yönetimi", İdari ve Mali Açıdan Türkiye'de Yerel Yönetimler (Ed. Mehmet Mecek, Mesut Doğan, Bekir Parlak), Bekad Yayınları, Antalya, ss.211-273.

ORTAYLI, İlber (1990), "Yerel Yönetim: Devraldığımız Miras", Türk Belediyeciliğinde 60 Yıl Sempozyumu Bildiriler Kitabı, Ankara Büyükşehir Belediyesi Metropol İmar A.Ş. Yayını, 23-24 Kasım 1990, Ankara, ss.63-74.

ORTAYLI, İlber (2000), Tanzimat Devrinde Osmanlı Mahalli İdareleri (1840-1880), Türk Tarih Kurumu Yayınları, Ankara. 
ÖZTÜRK, Ali İhsan (2010), Osmanlıdan Cumhuriyete İmtiyaz Usulüyle Yürütülen İstanbul Belediye Hizmetleri (1852-1864), İstanbul Büyükşehir Belediyesi Kültür A.Ş. Yayını, İstanbul.

PARLAK, Bekir (2020), Türkiye’de Yerel Yönetimler, Değişim Yayınları, İstanbul.

T. C. ADİLCEVAZ BELEDIYE BAŞKANLIĞI (2020), “Adilcevaz Tarihi”, Adilcevaz Belediye Başkanlı̆̆ı Kurumsal Web Sayfası, https://www.adilcevaz.bel.tr/adilcevaz/adilcevaz-tarihi (Erişim Tarihi: 19/07/2020).

T. C. AHLAT BELEDIYE BAŞKANLIĞI (2020), “Ahlat Tarihi”, Ahlat Belediye Başkanlığı Kurumsal Web Sayfası, https://www.ahlat.bel.tr/?page_id=806 (Erişim Tarihi: 19/07/2020).

T. C. İÇIŞLERİ BAKANLIĞI (2020), "Mülki İdare Birimleri”, İçişleri Bakanlığı Kurumsal Web Sayfası, https://www.e-icisleri.gov.tr/Anasayfa/MulkiIdariBolumleri.aspx (Erişim Tarihi: 10/12/2020).

T. C. TATVAN BELEDIYE BAŞKANLIĞI (2020), "Tatvan Tarihi”, Tatvan Belediye Başkanlığı Kurumsal Web Sayfası, http://www.tatvan.gov.tr/tatvan-tarihi (Erişim Tarihi: 19/07/2020).

TEKELİ, İlhan (1990), “Cumhuriyetin Altmış Ylllık Belediyecilik Deneyinin Değerlendirilmesi Üzerine”, Türk Belediyeciliğinde 60 Yıl Sempozyumu Bildiriler Kitabı, Ankara Büyükşehir Belediyesi Metropol İmar A.Ş. Yayını, 23-24 Kasım 1990, Ankara, ss.44-56.

TUNÇ, Ahmet (2016), "Yerel Yönetimlerde Halkla İlişkiler Uygulamaları: Kilis Belediyesi Örneği", Kahramanmaraş Sütçü İmam Üniversitesi İktisadi ve İdari Bilimler Fakültesi Dergisi, S.6(2), ss.7788.

TUNÇ, Ahmet, BELLİ, Aziz ve AYDIN, Abdullah (2019), "Yerelde Yönetişim Algısı Üzerine Bir Alan Araştırması: Kahramanmaraş Büyükşsehir Belediyesi Örneği”, Gaziantep Üniversitesi Sosyal Bilimler Dergisi, S.18(1), ss.256-270.

YILMAZ, Vedat (2019), "Doğu Anadolu Bölgesinde E-Belediyecilik Hizmetlerinin Yerel Halk Tarafindan Kullanım Düzeylerinin Değerlendirilmesi: Bitlis ve Muş Belediyesi Örnekleri”, E-Yönetişim (Ed. Bekir Parlak, Kadir Caner Doğan), Beta Yayınevi, İstanbul, ss.509-532.

YILMAZ, Vedat ve MECEK, Mehmet (2021), “Kavram ve Kuramsal Açıdan Türkiye'de Dijital Kamu Yönetimi ve Dönüşümü”, Kamu Yönetiminde Değişim Olgusu: Global Trendler ve Yeni Paradigmalar (Ed. Berat Akınc1), Nobel Yayınları, Ankara, ss.103-137.

https://www.nufusu.com/ilce/adilcevaz_bitlis-nufusu, (Erişim Tarihi: 30/07/2021).

https://www.nufusu.com/ilce/ahlat_bitlis-nufusu (Erişim Tarihi: 01/08/2021).

https://www.nufusu.com/ilce/tatvan_bitlis-nufusu (Erişim Tarihi: 30/07/2021). 